\title{
STUPŇOVITÁ STRUKTURA MEZINÁRODNÍHO PRÁVA: STRUKTURÁLNÍ ANALÝZA NAMÍSTO MYSTIKY PRAMENU゚
}

\author{
JÖRG KAMMERHOFER
}

\begin{abstract}
The Hierarchical Structure of International Law: Structural Analysis, not Mysticism of the Sources of Law

The prevalent doctrine of international law considers Article 38 of the Statute of the International Court of Justice to be an authoritative list of the sources of international law. There are, however, many theories about the sources of international law. Moreover, the traditional approach is burdened by many inconsistencies and misrepresentations. The 'Stufenbau' theory of the hierarchy of norms, founded by Hans Kelsen and Adolf Julius Merkl, is based on a legal-theoretically coherent approach and can therefore describe the complex structure of the international legal order in a more accurate manner. The Stufenbau theory views the legal order as a hierarchy of norms, connecting the rules and structuring them. In particular, the 'hierarchy of legal conditionality' explores the validity of norms and the circumstances of their formation. Legal norms can only be valid, if their creation is authorised by a higher norm and if the lower norm fulfils the requirements of the enabling provisions of the higher norm. Therefore, for every norm, there has to be a higher one, except for the highest enabling norm, which represents the positive-legal foundation of one particular legal order, the so called 'historically first constitution'. The Stufenbau theory offers three variants as to how international law could be structured. We cannot say which one of these is the correct, and that would not be the aim of the structural analysis anyway. The Stufenbau theory and the structural analysis it enables therefore help us to understand the complexities of international law better than other legal theories.
\end{abstract}

Keywords: international law, sources of international law, Article 38 of the Statute of the International Court of Justice, the hierarchical theory of norms, hierarchy according to the conditions of law-making, first historical constitution

Klíčová slova: mezinárodní právo veřejné, prameny mezinárodního práva, článek 38 Statutu Mezinárodního soudního dvora, teorie stupňovité struktury, podmínky vytváření práva, první historická ústava

DOI: $10.14712 / 23366478.2017 .21$ 


\section{1. ÚVOD 1}

Odborník na mezinárodní právo je nejprve konfrontován s „prameny“ mezinárodního práva a především s článkem 38 statutu Mezinárodního soudního dvora. Převládající právní nauka vidí v tomto článku autoritativní výčet právních pramenů, jinými slovy: Mezinárodní právo je přinejmenším odvozeno ze smluv, obyčejového práva a všeobecných právních zásad. Tato harmonie ovšem klame a debat o pramenech mezinárodního práva se vede spousta; nauka je navíc, nikoli překvapivě, prostoupena protichůdnými tezemi a také do značné míry pověrami. Abychom do houštiny tradičního chápání pramenů práva vnesli trochu světla, chceme v tomto článku pohovořit o poněkud jiném př́istupu: teorii stupňovité struktury právního řádu.

Odborníkovi na mezinárodní právo zde ukážeme, že pomocí této teorie je možné naplnit zvlášt' důslednou formu zdravého právního rozumu, nebot’ žádná jiná teorie práva není pro popsání struktury mezinárodního právního systému bez zkreslení vhodnější. Namísto pragmatismu, politizovaného „uznání“ a nekritického přejímání tradovaných autorit vychází teorie stupňovité struktury z právně-vědeckého ideálu čisté právní nauky a právně-teoretického kritického pohledu na argumenty dogmatiky. Teorie stupňovité struktury (Stufenbaulehre), jejímiž autory jsou Adolf Julius Merkl a Hans Kelsen, nám umožňuje odhlédnout od matoucí metafory pramenů a zaměřit se na právo tvorby právních předpisủ. Žádný jiný teoretický př́istup se tradičnímu porozumění pramenům neblíži více, zatímco se současně vyvarovává jeho chyb. ${ }^{2}$

Právnímu teoretikovi je na druhé straně mezinárodní právo a jeho nauka prezentována jako laboratoř pro teorii stupňovité struktury. Vznik a strukturu mezinárodního práva lze považovat za obzvláště poučný př́pad použití, nebot' jednoduché struktury norem a učení - které obecně stále silně připomínají etatistický pozitivismus 19. století - a absence sjednocující právnické či právní kultury umožňují vidět detailněji chyby běžných teorií o pramenech práva a lépe zdůraznit výhody teorie stupňovité struktury. Nauka o mezinárodním právu ovšem také jasněji odhaluje limity průkaznosti čisté právní nauky než například rakouská nauka o ústavním právu. Vnitrostátní právní kultura může být schopna zakrýt problémy, v mezinárodním právu ovšem zeje otevřená rána.

1 Tento příspěvek je přepracovaným německým zněním publikace: KAMMERHOFER, J.: Sources in Legal Positivist Theories. The Pure Theory's Structural Analysis of the Law. In BESSON, S. - D'ASPREMONT, J. (eds.): The Oxford Handbook of the Sources of International Law. Oxford, 2017, Dostupné z: https:// ssrn.com/abstract=2764238. K teorii stupňovité konstrukce viz již: KAMMERHOFER, J.: Uncertainty in International Law. A Kelsenian Perspective. Abingdon, 2010; KAMMERHOFER, J.: Robert Walter. Die Normkonflikte und der zweite Stufenbau des Rechts. In JABLONER, C. et al. (eds.): Gedenkschrift Robert Walter: Wien, 2013; KAMMERHOFER, J.: Hans Kelsen in Today's International Legal Scholarship. In KAMMERHOFER, J. - D’ASPREMONT, J. (eds.): International Legal Positivism in a Post-Modern World. Cambridge, 2014.

2 K různým typům teorie zdrojů podle Harta zde nelze $\mathrm{z}$ důvodu místa přihlédnout, $\mathrm{k}$ tomu viz: KAMMERHOFER, J.: Hans Kelsen in Today's International Legal Scholarship. Op. cit., s. 97-105; KAMMERHOFER, J.: International Legal Positivism. In HOFFMANN, F. - ORFORD, A. (eds.): The Oxford Handbook of the Theory of International Law. Oxford, 2016; KAMMERHOFER, J.: Positivistische Normbegründung. In HILGENDORF, E. - JOERDEN, J. C. (eds.): Handbuch Rechtsphilosophie. Stuttgart, 2017, s. 204-207. 


\section{TEORIE STUPŇOVITÉ STRUKTURY}

\section{1 „PRÁVNÍ ZDROJ“ JAKO METAFORA BRÁNÍCÍ POZNÁNÍ}

Mezinárodní právníci si - stejně jako pravděpodobně všichni právníci nejprve kladou jednu nejzákladnější otázku: „Jaké právo platí??“ nebo „Jaké právo platí, pokud jde o určitou konkrétní skutkovou podstatu?" Abychom na tuto otázku mohli odpovědět, nepotřebujeme ani absolutní důvod platnosti, ani konečnou definici „práva“. Tuto otázku bychom spíše měli vnímat alespoň na první pohled mnohem pragmatičtěji, protože se vlastně ptáme na to, kde právo „najít“: Odkud právo pochází? Jsou právní normy uplatňované účastníky řízení „skutečně“ součástí práva? Odpověd' na tuto otázku se zdá být jednoduchá, nebot' právo tvoří „právní prameny“ (zdroje) a předpokládané normy lze ověřit pomocí pramenů: Pokud vznikly v souladu s prameny, představují právo. Alespoň to tak vypadá. Ovšem člověk nemusí zacházet nijak hluboko do právně-filozofických úvah, aby toto chápání považoval za naivní. Prameny mohou být např́klad pouhým „,místem nálezu“, nikoli opodstatněním práva: Zdrojem poznání práva, nikoli zdrojem vzniku práva. ${ }^{3}$ Člověk v nich vyhledává, aby získal autoritativní znalosti práva, aniž by toto místo samo o sobě bylo opodstatněním práva. Navzdory těmto a mnoha dalším teoretickým problémům zůstává výše položená otázka akutní.

Zvlášt’ závažnou a destruktivní se ukázala být metafora právních „pramenů“ (,sources of law“). Představme si, že postupujeme po řece až k jejím pramenům, z nichž vyvěrá, a které se spojují a v širokém proudu plynou do údolí. ${ }^{4}$ Tento obrázek v sobě skrývá velkou moc, nebot' je velmi sugestivní, ovšem tím pádem také nebezpečný. Jako každá heuristika, tak i metafora pramenů stojí a padá se svým užitkem - je ale také silně omezená. $V$ průběhu doby byla důvodem vývoje dogmatických konstruktů, které za svou existenci vděčí pouze použitému obrazu, nikoli analýze dynamické struktury právního řádu; to vedlo k závažným „zkreslením“. Sám Kelsen v „Hlavních problémech“ hovořil o jednom z těchto konstruktů, totiž že vznik práva neprobíhal právně.

Stejně jako vysvětlující disciplíny nedokážou odpovědět na poslední otázky týkající se plození a ničení bytí, jsou metafyzické povahy, tak i problém vzniku a zániku práva ... za hranicemi formálních právních úvah, je ... metajuristické povahy. ... [J]en [historicky-sociologická úvaha], nikoli však normativně-formální úvaha jurisprudence zaměřená pouze na „Má být“", může zachytit „tvorbu práva“, vznik právního „Má být'“, tento metajuristický problém. ${ }^{5}$

3 BULÍN, H.: Die Konstruktion des Begriffes „Rechtsquellen“ im allgemeinen und der Quellen des römischen Rechts im besonderen vom Standpunkt der Reinen Rechtslehre. In KUBEŠ, V. - WEINBERGER, O. (eds.): Die Brünner rechtstheoretische Schule (Normative Theorie). Schriftenreihe des Hans Kelsen-Instituts 5. Wien, 1980.

4 OPPENHEIM, L.: International Law. A Treatise I. Longmans, 1905, s. 20-21.

5 KELSEN, H.: Hauptprobleme der Staatsrechtlehre entwickelt aus der Lehre vom Rechtssatze. Tübingen, 1911, s. 51, 89, 138, 181 a násl. 
Ovšem při přechodu $\mathrm{k}$ dynamickému pohledu na právní rád, ${ }^{6} \mathrm{k}$ němuž došlo přibližně kolem roku 1920, se Kelsen tohoto názoru vzdal a spolu s Merklem rozvinuli teorii stupňovité struktury, která na právní řád nahlíží jako na určitou stupňovitou pyramidu. ${ }^{7}$ Protože však sám Kelsen uvízl v pasti metafory pramenů, budeme muset převládající nauce o mezinárodním právu prominout, že jde tak úporně v jejích stopách; načrtněme si zde krátce některá z jejích zkreslení:

- Právní prameny nejsou samy o sobě právem.

- Prameny mezinárodního práva na sobě nejsou rovnocenně a platně závislé.

- Normy těchto vzájemně nezávislých pramenů se však přesto mohou navzájem ovlivňovat nebo dokonce derogovat.

- Vytváření norem prostřednictvím rozdílných metod znamená, že jedna metoda nutně odpovídá jednomu zdroji.

- „Právní pramen“ jako producent práva (tj. zdroj původu práva) se zaměňuje s právním produktem (tj. norma mezinárodního obyčejového je součástí pramene „mezinárodní obyčejové právo").

Tato metafora je jak prŕíčinou právně-teoretických chyb tradiční nauky o pramenech mezinárodního práva, tak současně príznakem hlubších problémů.

\subsection{OD PRAMENU゚ MEZINÁRODNÍHO PRÁVA KE STUPŇOVITÉ STRUKTUŘE}

Stupňovitá struktura je ovšem také obrazem vztahů norem právního řádu. Právní rád se na základě myšlenky hierarchické „,pyramidy norem“ nejen nemění, ale nemůže být ani pouhým heuristickým prostředkem. Teorie stupňovité struktury představuje mnohem více normově-teoretický př́stup, který zkoumá fungování jediného nezbytného vztahu mezi normami - vztahu platnosti. Teorie stupňovité struktury je produktem právní teorie a právní dogmatice má sloužit jako základ pro analýzu struktury pozitivních právních řádů. Ačkoli v moderních právních řádech obraz stupňovité pyramidy pravděpodobně postrádá na komplexnosti, není nutné odmítat právně-dogmatické výsledky vycházející z teorie stupňovité struktury, nebot' jak je uvedeno výše, obraz strukturu nemění. ${ }^{8}$ To proto, že myšlenka stupňovité struktury je výsledkem úvah o dynamických aspektech systémů norem, o ,[těch] strukturách a systematických vazbách, které jsou předem vytyčeny pojmem práva a vykazují tudíž právní charakter“. 9 Kdyby tedy konstrukce z betonu vypadala spíše jako sít’ než jako pyramida, nebyly by tím ani dogmatika, ani právní teorie házeny přes palubu.

6 PAULSON, S. L.: Zur Stufenbaulehre Merkls in ihrer Bedeutung für die Allgemeine Rechtslehre. In WALTER, R. (eds.): Adolf J. Merkl. Werk und Wirksamkeit. Ergebnisse eines Internationalen Symposiums in Wien (22.-23. März 1990). Schriftenreihe des Hans Kelsen-Instituts 14. Wien 1990, s. 41.

7 Na tomto př́ikladu je obzvlášt' patrné, že čistá právní doktrína je teorií vyvinutou společně a nikoli výhradně Kelsenovou zásluhou. Stupňovitá struktura byla především Merklovou myšlenkou a Kelsen, Merkl a další ji dále rozvinuli, viz KAMMERHOFER, J.: Robert Walter. Die Normkonflikte und der zweite Stufenbau des Rechts. Op. cit., s. 238.

8 MERKL, A. J.: Prolegomena einer Theorie des rechtlichen Stufenbaues. In VERDROSS, A. (eds.): Gesellschaft, Staat und Recht. Festschrift für Hans Kelsen zum 50. Geburtstag. Wien, 1931, s. 284, MerklGS I/1 s. 479 a násl.; LIPPOLD, R.: Recht und Ordnung. Statik und Dynamik der Rechtsordnung. Schriftenreihe des Hans Kelsen-Instituts 21. Wien, 2000, s. 386.

9 BEHREND, J.: Untersuchungen zur Stufenbaulehre Adolf Merkls und Hans Kelsens. Berlin, 1977, s. 11. 
Strukturální analýza práva je nejvíce vědeckou metodou právního poznání; strukturální analýza nás vede přímo k stupňovité struktuře právního řádu, nebot' otázka ohledně pramenů, je-li položena důsledně, se zaměřuje na to, co právo předepisuje ohledně vzniku práva. Ptáme se tedy výhradně práva na jeho vznik. Tento „autonomni'“ způsob uvažování znamená, že právní věda zůstává věrna svému předmětu a akademický právník nedovolí, aby jeho disciplína splynula se sociologií, psychologií nebo teorií morálky. To vede přímo ke stavbě systému ze zmocňovacích norem a k pozitivisticky-normativistické metodě.

Teorie stupňovité struktury vychází z kategorického oddělení ,je“ a „má být“; existuje pro ni právě jeden hierarchický koncept, který nutně vyplývá z myšlenky práva jako norem, jako „má být“", které je kategoricky oddělené od ,je“" ${ }^{10} \mathrm{Z}$ dichotomie je-má být a tím pádem z normativismu čisté právní nauky vyplývá zaprvé, že normy představují „,je“ (požadavek jejich dodržování), a zadruhé, že veškeré právo se skládá z norem. Normy mohou platit, tj. ve smyslu existence norem, ,existovat“ jen tehdy, když lze jejich platnost vysvětlit existencí nějaké další normy. ${ }^{11}$ Vždy je proto zapotřebí určitá norma, která by umožňovala vznik jiné normy. Norma, obrazně řečeno ,vyššíi“ nebo dokonce „Zdroj“, umožňuje hovořit o platnosti jiné, „nižší“ normy, a tudíž je původem její „existence“. Vzniká z toho právě ono spojení, které obráceně umožňuje regres platnosti. Objektivní platnost práva vyplývá z řádu, tj. ze spojení norem do normativního řádu; je tedy systémově formální.

Tento statický vztah odvození platnosti je však lépe pochopitelný, když se dynamicky mění. ${ }^{12}$ Zdrojová norma umožňuje vznik dalších norem, jejichž „existence“ z hlediska platnosti nutně vyžaduje zmocňovací ustanovení (není však dostačující), a které (proto) mohou být považovány za součást př́íslušného systému norem. „Nebot’ a pokud [norma] vznikla určitým způsobem, tj. způsobem určeným jinou normou, představuje tato norma bezprostřední opodstatnění její platnosti."13 Platí to ovšem také naopak: „Norma patří k právnímu řádu pouze proto, že je určována podle ustanovení jiné normy tohoto řádu. "14 Protože je platnost dceřiné normy závislá na mateřské normě, lze hovořit o vazbě obou těchto norem; právo upravuje svůj vlastní vznik. ${ }^{15}$

Právní prameny se tak z mysteria nehybného hybatele stávají stěžejním bodem systémů norem. Když si položíme otázku, odkud pochází právo a jak má právo vznikat, ptáme se na určitou část právního řádu, hledáme zmocňovací ustanovení. Tato zmocňovací ustanovení jsou sice ústřední součástí práva, teoreticky ovšem nejsou ničím více než určitou normativní funkcí: ${ }^{16}$ ty normy, které zmocňují lidi, aby vytvářeli normy. ${ }^{17}$

10 BEHREND, J.: Op. cit., s. 61.

11 KELSEN, H.: Reine Rechtslehre. Wien, 1960, s. 196.

12 MERKL, A. J.: Die Lehre von der Rechtskraft, entwickelt aus dem Rechtsbegriff. Eine rechtstheoretische Untersuchung. Leipzig, 1923, s. 217; STOITZNER, B.: Die Lehre vom Stufenbau der Rechtsordnung. In PAULSON, S. L. - WALTER, R. (eds.): Untersuchungen zur Reinen Rechtslehre. Ergebnisse eines Wiener Rechtstheoretischen Seminars 1985/86. Schriftenreihe des Hans Kelsen-Instituts 11. Wien, 1986, s. 55; viz rovněž PAULSON, S. L.: Zur Stufenbaulehre Merkls in ihrer Bedeutung für die Allgemeine Rechtslehre. Op. cit., s. 95.

13 KELSEN, H.: Reine Rechtslehre. Op. cit., s. 228.

14 Tamtéž, s. 239.

15 Tamtéž, s. 73; STOITZNER, B.: Op. cit., s. 55.

16 KELSEN, H.: Allgemeine Theorie der Normen. Wien, 1979, s. 82-84.

17 KELSEN, H.: Principles of International Law. New York, 1952, s. 303. 
„Zdroj“ je pak každé zmocňovací ustanovení, nikoli pouze některé „původní zdroje“ nebo „,nezbytný původ veškerého mezinárodního práva“.

Na druhé straně, synteticky nebo konstruktivně vzato, lze na základě takovéhoto nezbytného spojení mezi dvěma normami vysledovat strukturu celého systému norem a systémy norem brát vůbec nejprve jako celek a až poté jako konglomerát pravidel. ${ }^{18}$

Právní rád není systémem rovnocenných, vedle sebe postavených právních norem, ale stupňovitou konstrukcí různých vrstev právních norem. Jejich celek je dán vztahem, který vyplývá ze skutečnosti, že platnost normy vytvořené podle jiné normy je založena na této jiné normě, jejíž vznik je určován jinými; regres, který nakonec ústí do - předpokládané - základní normy. ${ }^{19}$

Toto strukturování podle vztahu platnosti nazývá Merkl stupňovitou strukturou podle právni podmínečnosti. ${ }^{20}$ Vztah vzniku je hierarchický; pouze pokud jsou splněny všechny podmínky zmocňovacího ustanovení (,pravidla vzniku práva“), může vzniknout norma př́slušného právního řádu. ${ }^{21}$ Ze spousty norem tak vzniká rád: „Aby mohl být chaos vytváření práva... vykládán jako právní vesmír, pak musí být... princip delegování... uznán jako projev společného původu“ “.22 Poněvadž aby mohl být zvlášt' důsledně zdůrazňován jen princip řádu, který je v právu již vymezen, nemůže se teorie stupňovité struktury setkávat s výčitkou idealizace práva. Stupňovitá struktura jako výraz imanentního uspořádání práva umožňuje také poznání více či méně komplexních struktur práva prostřednictvím právní vědy. Merkl nazývá tento proces „strukturální analýzou práva“, při níž jsou např. prostřednictvím vědy veřejného práva popisovány komplexní kaskády zmocňovacích norem, které jsou někdy spíše uspořádány v síti než pyramidálně. ${ }^{23}$ V nauce o mezinárodním právu jsou naopak struktury pravděpodobně (ale nikoli nutně) méně složité. Stupňovitá konstrukce je tedy „výsledkem právní strukturální analýzy, jejíž cíl poznání ... je ... upozornit na ty struktury a systematické vztahy, které jsou definovány pojmem práva a vykazují tak z hlediska práva kolísavý charakter“. ${ }^{24}$

Ten, kdo se od abstraktní teorie norem přesune k odborné právní analýze konkrétních právních řádů, ten rychle zjistí, že proti naprosté rozmanitosti skutečných nebo možných normativních obsahů stojí relativně omezený počet forem regulí. ${ }^{25}$ Tyto takzvané „právní formy“ jsou předmětem intenzivních diskusí v sekundární literaturè; základní myšlence čisté právní nauky s největší pravděpodobností odpovídá názor Roberta Wal-

18 LIPPOLD, R.: Op. cit., s. 402.

19 KELSEN, H.: Reine Rechtslehre. Op. cit., s. 228; viz rovněž MERKL, A. J.: Prolegomena einer Theorie des rechtlichen Stufenbaues. Op. cit., s. 257 = WRS s. 1317, MerklGS I/1 s. 443.

20 MERKL, A. J.: Prolegomena einer Theorie des rechtlichen Stufenbaues. Op. cit., s. $276=$ WRS s. 1340, MerklGS I/1 s. 468; WALTER, R.: Der Aufbau der Rechtsordnung. Eine rechtstheoretische Untersuchung auf Grundlage der Reinen Rechtslehre. Graz, 1964, s. 60; STOITZNER, B.: Op. cit., s. 55-56. Stupňovitou konstrukci podle derogační síly nelze v tomto př́spěvku diskutovat.

21 KELSEN, H.: Reine Rechtslehre. Op. cit., s. 239; LIPPOLD, R.: Op. cit., s. 399; BEHREND, J.: Op. cit., s. $16-17$.

22 MERKL, A. J.: Die Lehre von der Rechtskraft, entwickelt aus dem Rechtsbegriff. Eine rechtstheoretische Untersuchung. Op. cit., s. 210.

23 ÖHLINGER, T.: Der Stufenbau der Rechtsordnung. Rechtstheoretische und ideologische Aspekte. Wien, 1975, s. 17.

24 BEHREND, J.: Op. cit., s. 11; viz rovněž STOITZNER, B.: Op. cit., s. 51.

25 ZB MERKL, A. J.: Die Lehre von der Rechtskraft, entwickelt aus dem Rechtsbegriff. Eine rechtstheoretische Untersuchung. Op. cit., s. 207-209; Merkl, Prolegomena 252 = WRS 1311, Merk1GS I/1 437. 
tera: „Důvodem určení formy právních předpisů je pravidlo jejich vzniku; stejnou formu mají ty právní předpisy, které byly vytvořeny podle stejného pravidla vzniku." ${ }^{26}$ Pro tradiční nauku o mezinárodním právu by tyto právní formy představovaly pravděpodobně všechny normy, které pocházejí ze stejného zdroje. Podle tohoto chápání by tedy bylo celé mezinárodní obyčejové právo právní formou, nebot' všechny př́slušné normy byly vytvořeny na základě téže zmocňovací normy. Ovšem právě ve složitých právních rrádech - avšak za určitých okolností také v řádech $\mathrm{s}$ jednodušší strukturou, jako je mezinárodní právo - může analýza struktury zmocňovacích norem dospět $\mathrm{k}$ výsledku, který je na hony vzdálen zjednodušujícímu tradičnímu chápání hierarchie pramenů a norem. ${ }^{27}$ Skutečné pozitivní podmínky vzniku práva mohou být v rozporu s předpokladem sledu různých právních forem. ${ }^{28}$

\subsection{ORTODOXNÍ NAUKA O PRAMENECH MEZINÁRODNÍHO PRÁVA}

V úvodu byly zmíněny některé problematické postoje ortodoxní nauky o pramenech; čtyři nejdůležitější budou krátce popsány $\mathrm{v}$ této části a budou podrobeny kritice z pohledu teorie stupňovité struktury. Jako prríklad ortodoxní doktríny může sloužit př́spěvek Rüdigera Wolfruma k pramenům mezinárodního práva v „Max Planck Encyclopedia of Public International Law“. ${ }^{29}$

1. Externalita. V dogmatických spisech, jako je ten Wolfrumův, se tento symptom nachází jen skrytě, např.: ,[I]nternational law is constituted by legally binding norms, stemming from different sources. The term , sources' refers to ... the process and procedure through which binding rules of international law ... are generated.“ (překlad: Mezinárodní právo tvoří právně závazné normy pocházející z různých pramenů. Termín „zdroje“ odkazuje na ... proces a postup, pomocí něhož jsou závazná pravidla mezinárodního práva... vytvářena.) ${ }^{30}$ Prameny jsou tedy „mechanisms ... for the development of the international normative order", (mechanismy... pro rozvoj mezinárodního normativního ráádu) ${ }^{31}$ „,metody“, ,projevy“ nebo „postupy““.32 Z tohoto důvodu

26 WALTER, R.: Der Aufbau der Rechtsordnung. Eine rechtstheoretische Untersuchung auf Grundlage der Reinen Rechtslehre. Op. cit., s. 55; viz rovněž STOITZNER, B.: Op. cit., s. 57, 81-82 (FN 57).

27 LIPPOLD, R.: Op. cit., s. 393.

28 WIEDERIN, E.: Die Stufenbaulehre Adolf Julius Merkls. In GRILLER, S. - RILL, H. P. (eds.): Rechtstheorie: Rechtsbegriff-Dynamik-Auslegung. Wien, 2011, s. 92-100; ÖHLINGER, T.: Der Stufenbau der Rechtsordnung. Rechtstheoretische und ideologische Aspekte. Wien, 1975, s. 16-17.

29 WOLFRUM, R.: Sources of International Law. In WOLFRUM, R. (eds.): Max Planck Encyclopedia of Public International Law IX. Oxford, 2012.

30 Tamtéž, s. 300 RZ 6.

31 Tamtéž, s. 310 RZ 58.

32 PELLET, A.: Article 38. In ZIMMERMANN, A. - TOMUSCHAT, CH. - OELLERS-FRAHM, K. (eds.): The Statute of the International Court of Justice. Oxford, 2006, s. 700-701 RZ 75, FN 149-150; FITZMAURICE, G. G.: Some Problems Regarding the Formal Sources of International Law. In ASBECK, F. M. van et al. (eds.): Symbolae Verzijl. Présentées au Prof. J. H. W. Verzijl á l'occasion de son LXX-ième anniversaire. Den Haag, 1958, s. 154; SCHWARZENBERGER, G.: International Law. London, 1960, s. 24; JENNINGS, R. Y. - WATTS, A. (eds.): Oppenheim's International Law. London, 1992, s. 23; SHAW, M. N.: International Law. Cambridge, 2014, s. 49-51; STREBEL, H.: Quellen des Völkerrechts als Rechtsordnung. Zeitschrift für ausländisches öffentliches Recht und Völkerrecht, sv. 36, 1976, s. 302-303; VIRALLY, M.: The Sources of International Law. In SØRENSEN, M. (eds.): Manual of Public International Law. London, 1968, s. 120. 
jsou prameny bud” postupy, jejichž pomocí vzniká právo, ${ }^{33}$ nebo „formální“ pomocné prostředky k uznání práva (oproti důkazním prostředkům), nebo obojí - převládající nauka je $\mathrm{v}$ každém př́padě přesvědčena, že se nejedná o právní normy ani pravidla, ${ }^{34}$ že existují jaksi mimo nebo vně práva, at' jako výsadní entita nebo jako prostředek ke zjištění práva. ${ }^{35}$ Toto pojetí vidí prameny „pouze jako empirický popis postupů, během nichž obvyklým způsobem vznikají normy, které jsou pravidelně dodržovány... resp. brány jako zavazující' “. ${ }^{36}$ Zastánci ortodoxní nauky o mezinárodním právu si obvykle neuvědomují právně teoretické implikace svých postojů nebo si je nedovozují, proto lze o důvodech pouze spekulovat, např. možná rozdíl mezi právními prameny a opodstatněním mezinárodního práva: „The sources of the rules of law, while therefore distinct from the basis of law, are nevertheless necessarily related to the basis of the legal system as a whole.“ (překlad: „Prameny právních pravidel, ačkoli se odchylují od právního základu, nicméně nutně souvisejí se základy právního systému jako celku.") ${ }^{37}$ Přestože se prípouští, že ,source of a rule of law is ... to be found in the process ... from which it derives its legal validity“ (překlad: ,pramen právního pravidla lze ... nalézt $\mathrm{v}$ procesu... z něhož vyplývá jeho právní platnost"), ${ }^{38}$ není tím míněno, že je vhodné se zastávat opaku.

2. Rovnost důležitosti. Pro Wolfruma neexistuje (s výjimkou ius cogens) hierarchie pramenů. ${ }^{39}$ Zdroje nelze najít na různých místech mezinárodního právního řádu, nacházejí se na jednom určitém místě. ${ }^{40}$ Proto se nemohou podílet na hierarchii norem, jsou stejné a rovnocenné a stejným způsobem odděleny od (hmotných) právních pravidel. Podřízené prameny (chápané jako produkt), napřr. určitá usnesení Rady bezpečnosti OSN, jsou rovnocenné mezinárodněprávním smlouvám a mezinárodnímu obyčejovému právu, ${ }^{41}$ ačkoli zmocňovací norma usnesení se jednoznačně nachází ve smlouvě, konkrétně v Chartě OSN.

33 PELLET, A.: Op. cit., s. 777 RZ 277.

34 BOS, M.: The Recognized Manifestations of International Law. A New Theory of "Sources". German Yearbook of International Law, sv. 20, 1977, s. 10-11; CASSESE, A.: International Law. Oxford, 2005, s. 153; GIHL, T.: The Legal Character and Sources of International Law. Scandinavian Studies in Law 1, 1957, s. 83; HULSROJ, P.: Three Sources - no River. A Hard Look at the Sources of Public International Law with Particular Emphasis on Custom and "General Principles of Law". Zeitschrift für öffentliches Recht, sv. 54, 1999, s. 234; VERDROSS, A. - SIMMA, B.: Universelles Völkerrecht. Berlin, 1984, s. 323324.

35 K poslední variantě: D'ASPREMONT, J.: Formalism and the Sources of International Law. A Theory of the Ascertainment of Legal Rules. Oxford, 2011.

36 FASTENRATH, U.: Lücken im Völkerrecht. Zu Rechtscharakter. Quellen, Systemzusammenhang, Methodenlehre und Funktionen des Völkerrechts, Berlin, 1991, s. 86.

37 JENNINGS, R. Y. - WATTS, A. (eds.): Oppenheim 's International Law. London, 1992, s. 23; viz rovněž: MENON, P. K.: An Enquiry into the Sources of Modern International Law. Revue de Droit International, de Sciences Diplomatiques et Politiques 64, 1986, s. 181; CORBETT, P. E.: The Consent of States and the Sources of the Law of Nations. British Year Book of International Law, sv. 6, 1925, s. 20-30; VAN HOOF, G. J. H.: Rethinking the Sources of International Law. Deventer, 1983.

38 JENNINGS, R. Y. - WATTS, A. (eds.): Oppenheim's International Law. London, 1992, s. 23.

39 WOLFRUM, R.: Op. cit., s. 301 RZ 11; viz rovněž PELLET, A.: Op. cit., s. 778-780 RZ 282-288; SHAW, M. N.: International Law. Cambridge, 2014, s. 87-88.

40 Viz JENNINGS, R. Y. - WATTS, A. (eds.): Op. cit., s. 15, s. 23; FITZMAURICE, G. G.: Op. cit., s. 154.

41 BOS, M.: Op. cit., s. 10-11. 
3. Možnost derogace. Pokud s běžnou doktrínou mezinárodního práva přijmeme rovnocennost pramenů mezinárodního práva, dá se očekávat, že bude zastáván názor, že normy z různých pramenů se nemohou dotýkat. Opakem je př́ípad: „International law sources form a unity and, as such, influence and supplement each other. ... The relationship between the sources is to be established on a case-by-case basis“ (překlad: „Prameny mezinárodního práva tvoří celek a jako takové se navzájem ovlivňují a doplňují. Vztah mezi zdroji je třeba stanovit vždy př́ípad od prŕpadu." ${ }^{42}$ Vztah mezi paralelní, vzájemně nezávislou platností smlouvy a obyčeje ${ }^{43}$, rozvinutý v rozsudku Mezinárodního soudního dvora v př́ípadu Nikaraguy, se zploští na možnost vzájemné derogace.

4. Forma. Metody vytváření norem se někdy stávají prameny mezinárodního práva jednoduše proto, že je možné normy takto vytvářet, jako např́iklad smluvní právo prostřednictvím synallagmatické dohody nebo obyčejové právo prostřednictvím praxe. Wolfrum tvrdí, že protože ,[a] variety of mechanisms are available in international law to gain consent, uphold consent, or to ensure that a norm under consideration meets the principles of fairness, equity, and justice“ (překlad: „,[a] v mezinárodním právu je $\mathrm{k}$ dispozici řada mechanismů pro získání souhlasu, potvrzení souhlasu nebo zajištění toho, aby uvažovaná norma splňovala principy čestnosti, slušnosti a spravedlnosti“"), ${ }^{44}$ jsou tyto postupy pro vytváření mezinárodního práva vhodné a každý takový postup představuje zdroj práva.

\subsection{KRITIKA A REKONSTRUKCE}

Na tomto místě by bylo možné uvést více než čtyři zmíněné symptomy, ovšem tyto jsou pro problematiku typické a jsou rozebírány v následující kritice. Rozhodující doktrína snad vychází z toho, že se „objevilo“ hmotné mezinárodní právo, aniž by byl samotný tento proces nějak právně regulován, nebot' mezinárodní právo nezná žádnou psanou ústavní listinu a sama myšlenka ústavy mezinárodního práva je odmítána. ${ }^{45}$ Situaci dnešní nauky o mezinárodním právu lze potud srovnat s německou naukou o státním právu z počátku 19 . století. ${ }^{46}$ Vzhledem $\mathrm{k}$ tomu, že přinejmenším smlouva, obyčejové právo a všeobecné právní principy se považují za původní zdroje mezinárodního práva, a nejsou tedy upravovány jinými normami, zdá se, že jejich vznik je věcí politiky nebo státní filozofie a nikoli práva. Myšlenka, že prameny práva jsou samy právem a že ústavy jsou v souladu s právem, byla populární v německy hovořících zemích až v průběhu 19. století - i zde je nauka o mezinárodním právu spíše izolovanou vesnicí v „provincii vzdálené od centra mysli““. ${ }^{47}$

Ovšem i když jsou motivy převládající nauky srozumitelné, postoj díky tomu není přijatelnější. Ten, kdo vidí právní prameny jako něco jiného než právo, tj. jako normy,

42 WOLFRUM, R.: Op. cit., s. 311, 300 RZ 60, 6.

43 Military and Paramilitary Activities in and Against Nicaragua (Nicaragua v. United States of America), Merits, Rozsudek ze dne 27. června 1986, ICJ Reports (1986)14 (95, 96 RZ 177, 179).

44 WOLFRUM, R.: Op. cit., s. 300 RZ 4.

45 D'AMATO, A. A.: The Concept of Custom in International Law. Ithaca, 1971, s. 91.

46 ZB STOLLEIS, M.: Geschichte des öffentlichen Rechts in Deutschland II: Staatsrechtslehre und Verwaltungswissenschaft 1800-1914. München, 1992, s. 99-102.

47 KELSEN, H.: Reine Rechtslehre. Op. cit., s. IV. 
ten musí být schopen postavit se námitkám, že podporuje určitou libovolnost, nebot’ právo pak může vzniknout každou „metodou“, pokud je pro proponenta přijatelná. Další námitka je založena na kategorickém oddělení „Je“ a „Má být“. Pokud by šlo právo zredukovat na skutečnosti, nemohly by být normy rozpoznány, nemohlo by se o nich mluvit a vůbec by nebylo možné si je představit v mysli. ${ }^{48}$ Smysl př́kazu ,sedni si!“ by byl nesrozumitelný. Ten, kdo uznává zakazovací nebo rozkazovací normy, ovšem přesně toto dělá: jsou „něčím“, co se má dodržovat, pokyny k chování, které ovšem podle okolností ve skutečnosti dodržovány nejsou. Proč by měly být zmocňovací normy uznávány jinak než normy chování? Pokud mají být ideály něco kategoricky jiného než realita, pak by musel být vznik norem upravován normami, nebot' pokud by normy utvářely pouze skutečnosti, pak by se obě kategorie přkekrývaly. Skutečné postupy jsou samozřejmě součástí vzniku práva - zmocňovací normy předepisují např. průběh voleb nebo publikaci ve sbírce zákonů - ovšem nepředstavují dostatečnou podmínku pro vznik práva. Politologicky řečeno je obsah právních norem spolurozhodován zcela neprávními faktory: Znásilnění je zakázáno v neposlední řadě proto, že takové chování je z morálního hlediska považováno za zavrženíhodné; řídit motorová vozidla pod vlivem alkoholu je zakázáno, protože je žádoucí předcházet dopravním nehodám. Tyto motivy ovšem nejsou opodstatněním těchto zákazů.

Jestliže jsou prameny právního řádu považovány za nutně rovnocenné, pak se myšlenka nutnosti vyvyšuje nad vědecko-právní analýzu „skutečné“ pozitivně-právní struktury tohoto právního řádu. Je dobře možné, že smlouva, obyčejové právo a všeobecné právní principy jsou také „,rovnocenné“", ovšem není to nutně tak. Tím, že teorie stupňovité struktury staví do popředí vědecko-právní analýzu zmocňovacích norem pozitivního práva, pomáhá nám rozpoznat, že je otázkou konkrétní úpravy pozitivního práva, jak jsou prameny mezinárodního práva uspořádány, a úkolem právní dogmatiky je zjistit, jak, kde a jaké zmocňovací normy platí v mezinárodním právu, a jaké normy na jejich základě vznikly nebo mohou vzniknout. A fortiori to platí pro otázky derogace, nebot' bez vztahu podřízenosti neexistuje žádný vztah platnosti ani mezi dvěma zmocňovacími normami, ani mezi normami, které vznikly na jejich základě. V zásadě ${ }^{49}$ proto pro rovnocenné zdroje platí, že neexistují žádné vztahy derogace.

\section{STUPŇOVITÁ STRUKTURA V MEZINÁRODNÍM PRÁVU}

Při přechodu od právní teorie k právně-teoreticky informované dogmatice mezinárodního práva má být nyní na základní problém obyčejového práva v oblasti mezinárodního práva použita teorie stupňovité struktury: v porovnání s národními právními řády relativně větší nejistota ohledně toho, jak je tvořeno nejvyšší zdrojové právo. Tímto způsobem lze sice ,vyřešit“ jen několik problémů, ovšem přinejmenším může být otázka položena ,čistěji“, tj. takovým způsobem, aby teorie a pozitivní právo nebyly vzájemně míchány, aby vědecké metody, které spolu nejsou vzájemně sladěny, nebyly

48 KELSEN, H.: Allgemeine Theorie der Normen. Op. cit., s. 49.

49 Srov. ovšem KAMMERHOFER, J.: Uncertainty in International Law. A Kelsenian Perspective. Op. cit., s. 139-194. 
házeny do jednoho hrnce, a aby politické preference nebyly vydávány za zájmy o poznání. $Z$ tohoto důvodu je třeba se v následující části věnovat některým dopadům teorie stupňovité struktury na úpravu nejvyšších zmocňovacích norem mezinárodního práva.

Relevanci tohoto problému pro každodenní právně dogmatickou práci může ilustrovat stručný př́klad. Odborníci na mezinárodní právo se ptají, za jakých předpokladů vzniká mezinárodní obyčejové právo. Vzorec: „usus plus opinio iuris rovná se zvykové právo“ je známý, ovšem ani na této velmi abstraktní úrovni nepanuje jednota. Existují důležité hlasy, které by se jednoho nebo druhého prvku vzdaly. I když se to považuje za scestné a jak praxe, tak rovněž právní přesvědčení jsou brány jako nezbytné, není jisté, co je právě nyní nutné pro naplnění dvou podmínek skutkové podstaty. Převládající naukou a stálou judikaturou např́ílad je, že pro vznik obyčejového práva je relevantní „verbální praxe“, např. vyjadřování stanovisek, smlouvy z oblasti mezinárodního práva nebo rezoluce OSN. Mělo by zůstat nerozhodnuto, zda je tomu tak. Relevantní je, k jakému typu argumentace nauky patří. Otázka akademického právníka by měla znít: „Jak je uspořádáno pravidlo vzniku mezinárodního obyčejového práva?" Metodicky špatný je postup ortodoxní doktríny, která spadá do nekritického „empirismu“ a jejíž argumenty se pohybují v kruhu. Verbální praxe je relevantní, protože se na ně všichni - včetně soudů - spoléháme: „[T]he above authorities (výše uvedené autority) [které verbální praxi upírají právní relevanci] cannot support their views on State practice with State practice" (nemohou podpořit své názory $n a$ státní praxi pomocí státní praxe)..$^{50}$

Jak je uvedeno výše, ortodoxní doktrína je toho názoru, že právní prameny jou pouhými „metodami“ nebo „postupy“ k vytváření práva a že jsou založeny na faktech: pouze z chování a akceptace se určuje, jak právo vzniká. Pokud je však mezinárodní právo normou, pak i jeho zdroje musejí být právními normami. Právo určuje na jedné straně podmínky skutkové podstaty pro vznik práva (tedy napr. ,,usus a opinio“), ovšem na druhé straně také počet, hierarchické postavení a vztah mezi prameny mezinárodního práva. Jednalo by se o určité meta-meta-právo vzniku pramenů. Platí tedy, že je třeba najít takové pravidlo vzniku práva, které upozorňuje na to, jak vznikají „nejvyšší“ zmocňovací normy. ${ }^{51}$

Teorie stupňovité struktury dala této nejvyšši úrovni pozitivních norem dva názvy: jednak „materiální ústava“ , 52 a jednak „historicky první ústava“-v každém př́ípadě jde o základní pozitivní normy právního řádu, zde: mezinárodního práva. ${ }^{53}$ Úlohou nauky o mezinárodním právu je tudíž ,,analýza pozitivních právních zásad ústavy mezinárodního práva“"54.

50 VILLIGER, M.: Customary International Law and Treaties. A Manual on the Theory and Practice of the Interrelation of Sources. Den Haag, 1997, s. 19-20.

51 RUB, A.: Hans Kelsens Völkerrechtslehre. Versuch einer Würdigung. Zürich, 1995, s. 312-313.

52 KELSEN, H.: Reine Rechtslehre. Op. cit., s. 228; viz rovněž: ALEXY, R.: Hans Kelsens Begriff der Verfassung. In PAULSON, S. L. - STOLLEIS, M. (eds.): Hans Kelsen. Staatsrechtslehrer und Rechtstheoretiker des 20. Jahrhunderts. Tübingen, 2005, s. 333.

53 KUNZ, J. L.: The "Vienna School" and International Law. New York University Law Quarterly Review, SV. 11, 1934, s. 412.

54 MÉTALL, R. A.: Skizzen zu einer Systematik der völkerrechtlichen Quellenlehre. Zeitschrift für öffentliches Recht, sv. 11, 1931, s. 421. 


\subsection{ZDROJOVÁ ARCHITEKTURA MEZINÁRODNÍHO PRÁVA}

Jak by tedy mohla být taková stupňovitá konstrukce mezinárodního práva strukturována? V mezinárodním právu jsou hranice našeho právního uznání daleko užší, než je tomu v oblasti vnitrostátního práva. Vycházíme-li arguendo z toho, že ortodoxní názor je pravdivý přinejmenším do té míry, pokud podle článku 38 Statutu Mezinárodního soudního dvora existují smlouva, obyčejové právo a všeobecné právní zásady. Logicky existují tři možnosti, jak by tyto tři prameny mohly být ve stupňovité konstrukci uspořádány.

1. Jeden z pramenů je původní a ten nejvyšší, ostatní zdroje jsou z něho odvozeny. Zmocňovací normy ostatních se nacházejí v těch normách, které podle nich byly vytvořeny. ${ }^{55}$ Mohlo by se jednat o smluvní právo, ovšem taková ústavní smlouva jednoduše neexistuje. Ani samotná Charta OSN ani Statut Mezinárodního soudního dvora tuto funkci nevykonávají, zejména proto, že článek 38 upravuje pouze rozhodné právo pro soud, nikoli veškeré zdroje mezinárodního práva. Vrchol hierarchie pramenů by mohlo tvořit také zvykové právo, jak v každém př́padě zastával Kelsen v roce 1952. ${ }^{56}$ Zmocňovacími normami, např. pro mezinárodněprávní smlouvy (pacta sunt servanda), by tak vždy byly samy normy obyčejového práva. Opinio iuris se pro to možná dá najít, ovšem $\mathrm{k}$ vytvoření tohoto typu norem je zapotřebí také usus. Je ovšem velmi pochybné, zda skutkovou podstatu zmocnění - Má být - lze skutečně zachytit prostřednictvím faktické pravidelnosti jednání (praxe). ${ }^{57}$

$1 \mathrm{a}$

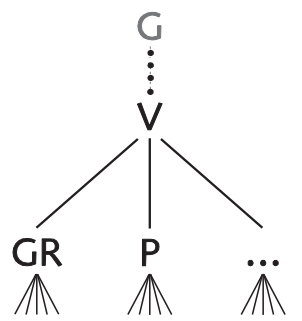

$1 \mathrm{~b}$

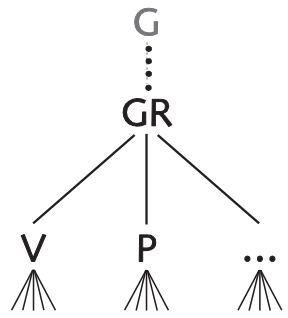

$1 c$

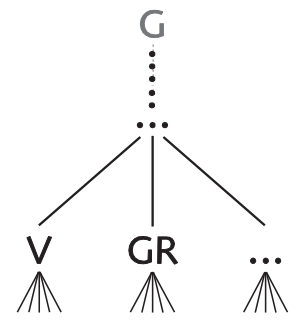

Obrázek 1: Varianta 1 - Zdroj mezinárodního práva je nejvýše. ${ }^{58}$

2. Skutečné mezinárodní ústavní právo, pozitivní zmocňovací norma, stojí nad všemi prameny mezinárodního práva, např́iklad ve formě mezistátního konsenzu, o němž hovoří Verdross: ${ }^{59}$ „Vedl... v hodině zrození mezinárodního práva... k uznání smluv, obyčejového práva a všeobecných právních zásad jako... formálních způsobů vzniku

55 RUB, A.: Hans Kelsens Völkerrechtslehre. Versuch einer Würdigung. Zürich, 1995, s. 337.

56 KELSEN, H.: Principles of International Law. Op. cit., s. 418.

57 KAMMERHOFER, J.: Uncertainty in International Law. A Kelsenian Perspective. Op. cit., s. 72-74.

58 Legenda ke všem obrázkům: G: Grundnorm > základní norma, V: Völkervertragsrecht > mezinárodní smluvní právo, GR: Völkergewohnheitsrecht > mezinárodní obyčejové právo, P: allgemeine Rechtsprinzipien > všeobecné právní zásady, ...: další zdroje, VVR: Völkerverfassungsrecht, $\mathrm{N}_{\mathrm{A}, \mathrm{B}, \ldots}:$ Verhaltensnormen.

59 VERDROSS, A. - SIMMA, B.: Universelles Völkerrecht. Berlin, 1984, s. 324. 
mezinárodního práva،“60 První normy mezinárodního práva by tedy „nevznikly ani na základě formální ústavní smlouvy, ani prostřednictvím opakované praxe mezinárodního práva, nýbrž na základě neformálního konsenzu mezi tehdejšími mocipány “ ${ }^{\text {“ }}{ }^{1}$ který by ovšem nepředstavoval „žádný hypotetický útvar, nýbrž soustavu norem, které skutečně tvoří základ mezinárodnímu obyčejovému právu i formálnímu smluvnímu právu“. 62 Je pravda, že Verdross nepovažuje konsenzus za opodstatnění mezinárodního práva, ${ }^{63}$ dalo by se však arguendo pro zde sledovaný účel předpokládat, že to tak je. Konsenzus by pak byl skutkovou podstatou nejvyšší pozitivní normy mezinárodního práva, a tudíž takzvanou „historicky první ústavou“ mezinárodního práva. ${ }^{64}$ Tato formulace se zdá pro mezinárodní právo neobvyklá, ovšem Kelsenovy úvahy jsou zakotveny v ústavní debatě a tento terminus technicus se vžil. Kelsen ji objasňuje v rámci regresu platnosti takto:

[Z]eptáme-li se na důvod platnosti norem, které upravují vznik obecných norem... dostaneme se možná ke starší státní ústavě; to znamená: platnost stávající státní ústavy odůvodňujeme tím, že vznikla podle ustanovení předcházející státní ústavy prostřednictvím ústavní změny ústavy...; a tím pádem [se dostaneme] nakonec $\mathrm{k}$ historicky první státní ústavě, kterou již nelze odvodit z další [pozitivní] normy, státní ústavy, která vstoupila $v$ platnost... revolučním procesem... ${ }^{65}$

Historicky první ústava je hierarchicky nejvyšší pozitivní normou pozitivního systému norem. Není spojena s žádnou další pozitivní zmocňovací normou a její platnost je předpokládána prostřednictvím základní normy ${ }^{66}$. Tato historicky první ústava je zdůrazňována i v mezinárodním právu, nebot je nezbytnou součástí každého právního řádu a z právního hlediska určuje zdroje práva. Teoreticky by fungovala i druhá varianta, je zde však jeden právně-dogmatický problém, nebot' bychom museli nejprve dokázat, že taková norma byla skutečně vytvořena. Jak by ovšem bylo možné dokázat, že takový akt vůle vưbec existoval? Zdá se nemožné a také nepravděpodobné, že by společenství

2

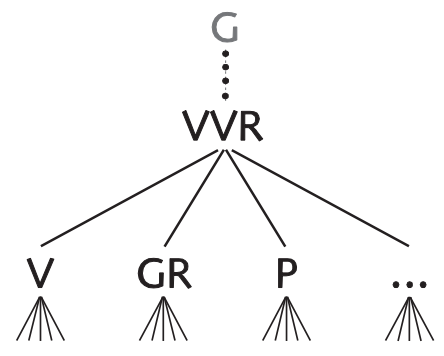

3

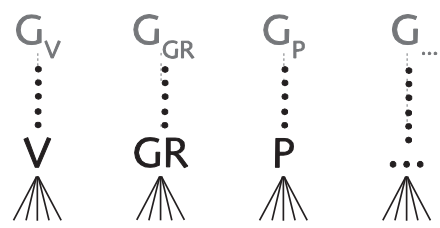

Obrázek 2: Varianta 2 - Pozitivní ústavní norma nad zdroji; varianta 3 - Každý zdroj je vlastním právním řádem.

60 Tamtéž, s. 324.

61 VERDROSS, A.: Die Quellen des universellen Völkerrechts. Freiburg, 1973, s. 20.

62 Tamtéž, s. 20-21.

63 VERDROSS, A. - SIMMA, B.: Universelles Völkerrecht. Op. cit., s. 327.

64 KELSEN, H.: Principles of International Law. Op. cit., s. 411.

65 KELSEN, H.: Reine Rechtslehre. Op. cit., s. 203.

66 MÉTALL, R. A.: Op. cit., s. 421. 
států přibližně v době uzavření Vestfálského míru výslovně nebo implicitně dosáhlo konsenzu ohledně vzniku původních norem mezinárodního práva (tedy pramenů mezinárodního práva). Bez důkazu pozitivity ovšem nemůžeme vycházet z pozitivní ústavní normy.

3. Třetí varianta je nejpravděpodobnější, teoreticky nejzajímavější, ovšem není nejestetičtější. Pokud mezi zdroji mezinárodního práva neexistuje žádný vztah platnosti, pak spolu tyto zdroje také nejsou propojeny. Tyto tři zdroje nejsou ve stejném vztahu vzniku ani hierarchickém vztahu a nejsou součástí téže stupňovité konstrukce. ${ }^{67}$ To by znamenalo, že když hovoř́me o „mezinárodním právu“, máme na mysli nikoli jeden, ale trri (nebo více) právních řádů. Pojem „mezinárodní právo“ by pak neoznačoval jeden právní řád; nejednalo by se o výsledek strukturální analýzy platného práva, ale o empirickou klasifikaci skupiny právních řádů.

\subsection{MƯŽE BÝT ZÁKLADNÍ NORMA SPOJUJÍCÍM PRVKEM?}

Jsou-li tedy zdroje mezinárodního práva všechny rovnocenné a nezakládají-li se na sobě ani na společné ústavě, pak neexistuje žádný vztah platnosti a třetí varianta je jediným zbývajícím řešením. Může ryzí nauka právní v tomto případě „,zachránit“ jednotu mezinárodního právního řádu, nebo je nutné se omezit na konstatování její fragmentace? Jestliže tedy strukturální analýza vztahů platnosti vede k výsledku, že zdroje nejsou propojené, např́klad jestliže vznik smluv v oblasti mezinárodního práva nebyl zmocněn pozitivní normou, pak musí být - pacta sunt servanda - předpokládána základní norma, aby bylo vůbec možné uznat smluvní právo jako normy. Základní norma, ,která ustanovuje jednotu celé řady norem tím, že představuje základ pro platnost všech norem náležejících $\mathrm{k}$ tomuto řádu“, 68 tedy současně vylučuje všechny normy, které k právnímu řádu nepatř́i. Jako epistemický mechanismus - všichni předpokládají, i nevědomky, základní normu, jestliže uznávají něco jako normy - základní norma neurčuje obsah pozitivního právního řádu, ale řídí se naopak podle obsahu nejvyšší pozitivní normy, tj. historicky první ústavy. Není pozitivní normou, která nařizuje, co by mělo právo být, ale to, co se děje, když něco uznáváme jako normu. V normo-ontickém smyslu nic nevytváří - pouze nám pomáhá uznávat. Proto základní norma také nemůže spojovat dvě nejvyšší pozitivní normy - tedy např. „pacta sunt servanda“ a „,onsuetudines sunt servanda“ - do jednoho jediného řádu norem, nebot' „se omezuje na zř́zení autority pro vydávání právních předpisů, a je proto koncepčně již podle svého obsahu jen singulární“ ${ }^{69}$ Proto také nemůže tvořit spojovací prvek tam, kde pozitivní právo žádný nepředpokládá. Akademičtí právníci nemohou spojovat dva systémy norem tím, že si nad nimi představí spojující a sjednocující základní normu.

67 Možná: KELSEN, H.: Das Problem der Souveränität u. die Theorie des Völkerrechtes. Der soziologische u. der juristiche Staatsbegriff. Mohr, 1928, s. 106-107.

68 KELSEN, H.: Reine Rechtslehre. Op. cit., s. 197. Viz rovněž MÉTALL, R. A.: Op. cit., s. 416; BEHREND, J.: Op. cit., s. 68-69; WALTER, R.: Der Aufbau der Rechtsordnung. Eine rechtstheoretische Untersuchung auf Grundlage der Reinen Rechtslehre. Op. cit., s. 47; WALTER, R.: Entstehung und Entwicklung des Gedankens der Grundnorm. In WALTER, R. (eds.): Schwerpunkte der Reinen Rechtslehre. Schriftenreihe des Hans Kelsen-Instituts 18. Wien 1992, s. 92-93.

69 BEHREND, J.: Op. cit., s. 28. 
Zcela myslitelný je ovšem i opačný pohled a z velké části je také slučitelný s čistou právní doktrínou. Je pravda, že i z tohoto pohledu je pro uznání norem nezbytná základní norma, tu však lze přijmout na libovolném místě stupňovité struktury. ${ }^{70}$ Proto si lze představit také základní normu, která je zřízena velmi komplexně a vzdáleně připomíná „rule of recognition“ (překlad: pravidlo uznání) Herberta Harta. Do základní normy by také mohl být zahrnut celý obsah př́slušných zmocňujících norem. V př́padě mezinárodního obyčejového práva by se jednalo o nauku dvou prvkủ, časové, kvalitativní a kvantitativní předpoklady, definice opinio iuris a mnohé další. Lze tak rekonstruovat rovněž pozici ortodoxní nauky o pramenech, která představuje zdroje mezinárodního práva jako pouhá fakta; tuto pozici $\mathrm{v}$ každém př́ípadě podporuje krajní případ toho nejjednoduššího myslitelného systému norem. $\mathrm{V}$ tomto myšlenkovém experimentu by platila jen přesně jedna pozitivní norma - např. člověk, který ještě nikdy předtím neformuloval žádný př́kaz, by nyní jinému nařizoval, aby vstal - a tato norma by byla uznatelná jako norma pouze tehdy, pokud by byla předpokládána tomu odpovídající základní norma. $V$ tomto príípadě by podmínky pro vznik pozitivní normy byly začleněny do základní normy a nejvyšší pozitivní norma by nebyla zmocňovací normou, nýbrž normou chování.
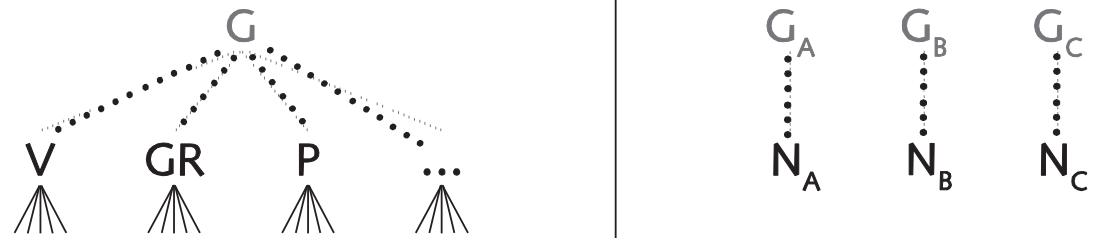

Obrázek 3: Vlevo - Komplexní základní norma tvoří spojovací prvek; Vpravo - Mezní př́ípad, kdy každá jednotlivá norma představuje vlastní systém norem.

Je dobře možné, že místo, kde se ve struktuře (údajné) stupňovité konstrukce předpokládá základní norma, je libovolné a že tato svoboda přispívá k fragmentaci myšlenky systému norem, resp. právní věda nabízí pro utváření strukturální analýzy velkou svobodu. ${ }^{71}$ Přesto nemůže žádný z obou popsaných strategických postupů systém mezinárodního práva platně sjednotit, když nelze prokázat pozitivně právní spojení. Úlohou právní vědy je uznat pozitivní právo takové, jaké ,je“, nikoli takové, jaké by „,mohlo být" - $\mathrm{k}$ tomu patří, že základní norma jako předpoklad uznání nemůže být náhradou za pozitivně právní vztah platnosti. I v samotném mezním př́íladu nejjednoduššího systému norem by se obsah základní normy řídil podle pozitivních norem. Norma A by pak měla základní normu A, ale již další norma chování (norma B) by měla základní normu B a nikoli obecnou verzi základní normy, která by sjednocovala podmínky vzniku pro normu A a B.

70 KAMMERHOFER, J.: Uncertainty in International Law. A Kelsenian Perspective. Op. cit., s. 193.

71 Tamtéž, s. 187-193, s. 235. 


\section{ZÁVĚR}

Ústava mezinárodního práva, nejvyšší úroveň stupňovité konstrukce je spekulativní. Ovšem ani „anything goes“ (překlad: všechno jde) tu neplatí. Zde zvlášt’ platí, že je třeba pracovat metodicky čistě; čistá právní nauka zde není překonána teorií právní vědy. Myšlenka omezit právní vědu na to, aby na jedné straně co možná nejpřesněji popisovala a analyzovala pozitivní normy určitého systému norem a na druhé straně tyto normativistické poznatky nemíchala s empirickými, psychologickými nebo politologickými, není ani jednoduchá ani nevede k pohodlným řešením. O to však čisté právní nauce ani nejde: Naši disciplínu chápe jako analytickou, zkoumavou a vědeckou. Právní věda - nikoli všichni právníci - by měla upozorňovat na problémy a analyzovat je; ,řešit“ je může jen velmi omezeně. V žádném př́padě se necítí povolána zbavovat politiku rozhodování prostřednictvím aplikace elitářského ,právnického práva“. Je výhodné přesáhnout pohodlné předpoklady ortodoxní dogmatiky mezinárodního práva a neopustit přitom základ pozitivního práva. Teorie stupňovité struktury jako teoretického základu strukturální analýzy pozitivního práva nám pomáhá vidět mezinárodní právo jasněji se všemi jeho „slabinami“ a „mezerami“ - a právě tyto přesnější vědomosti a jasnější vhled do struktury práva jsou pro pokrok právní vědy stěžejní. Jinak by nám každodenní operace aplikace práva zůstaly zcela nevyhnutelně záhadou. A není trocha půstu, konec obžerství argumentů a metod cenou, kterou bychom měli být akademickým právníkủm ochotni zaplatit za lepší znalosti našeho předmětu?

Dr. Jörg Kammerhofer, LL. M

University of Freiburg, Faculty of Law

joerg.kammerhofer@jura.uni-freiburg.de 